AREAL RESEARCH IN THE SOUTHERN TETONS: THE ARCHAEOLOGY OF SOUTHERN JACKSON HOLE

Thomas E. Marceau

State University of New York at Albany

\title{
Objectives
}

Objectives of the 1978 field season, briefly stated, were as follows:

(1) survey, collect, and test 48TE498; (2) complete the survey of the southern Teton Range concentrating on the area from Granite Canyon to Teton Pass; and (3) survey, collect, and test $48 \mathrm{TE} 655$.

Sawmi 11 Ponds (48TE498)

In all, 21 days were spent at this location. The site lies less than two (2) miles south-southwest of the entrance to Grand Teton National Park at Moose. It occupies a broad, relatively flat terrace above an old meander channel of the Snake River at an approximate elevation of 6500'. Sagebrush (Artemisia sp.) and lodgepole pine (Pinus latifolia) are the predominant vegetation. Soil consists of glacial outwash gravels and silt.

\section{Prehistoric Utilization}

212 collecting units, each $5 \times 5$ meters, were established. Artifacts from this 5300 square meter section were plotted on individual sheets of graph paper. Employing a surveyor's transit and metric tapes, the location of cultural materials lying beyond the gridded section was determined. In this way, a scaled surface distribution map was produced. This map will provide the basis for future cluster analyses.

Analysis of the lithic remains has yet to progress beyond the preliminary stages. We are presently testing a random sample of 175 pieces representing 336 worked edges. Specifically, we are experimenting with alternative methods of numerical taxonomy. Results are too inconclusive to be of value in this report. All pieces under consideration were obtained during the surface collection.

Five (5) $|x|$ meter test units have established the presence of a subsurface distribution of cultural items to a level of approximately 60 centimeters. Relationships between surface and subsurface materials remain to be demonstrated.

Hearths as well as charcoal are absent at this site. Together with the recovery of only fragmented or "unique" projectile points makes the assignment of a temporal range difficult. On the basis of current evidence no dates are proposed. 
Historic Utilization

The only feature encountered consisted of two perpendicular rows of quartzite cobbles, one running east-west, the other north-south. The former was approximately six (6) meters while the latter was close to nine (9) meters. Information provided by a long-time resident revealed that these lines had once supported the south and west walls of a temporary log structure which had served as a post office for Moose, Wyoming ca. 1926-1927. Little historic material was observed in association with this feature.

\section{High Country Survey}

Survey conducted this summer (1978) reaffirmed an hypothesis which relates most high country sites (i.e., +8000') to areas with limestone substratum. Two types of sites were noted: (1) activity loci, and (2) base camps. Bedrock in the central and south-central Tetons is predominantly granite (Love, 1975). Archaeological sites discovered in this zone are made up of thin, dispersed scatterings of artifactual materials. Moreover, there are few of these with regards to the total area investigated. We propose that these attenuated scatters were temporary, task-specific locations. In contrast, a number of base camps have been recorded in association with the limestone shelfs in the southern section of the Tetons. Some of these camps are quite large (e.g., the JEM site) and are characterized not only by a variety of raw materials but also by a rather full inventory of tool types. Additional task-specific loci were mapped in this southern zone; two will be discussed briefly.

Locus \#9

An archeological site located on the north rim of Moose Creek Divide Basin at an elevation of $8800^{\prime}$, this lithic scatter was small both in areal spread and item frequency. Obsidian was the preeminent raw material, quartzite and chert played minor supporting roles. Situated on an elevated knoll and screened by stands of pine, the location is well protected from the elements. The place of this site in the high country utilization has not been determined. The artifacts likewise await analysis.

Locus \#11

Positioned at the eastern terminus of a small snowfield, this locus is protected by knolls to the west and south, by the talus slopes of Fossil Mountain to the north and northwest, and by a high, flat area to the east. Melting snow provides a steady water source both in the form of running streamlets and a small collecting pond which forms the southern boundry of the site. The lithic scatter extended little beyond the immediate basin. 625 square meters were collected and artifact distributions mapped. Again, obsidian was the preferred raw material. These artifacts also await further analysis. 
The JEM site (48TE655)

Seven days were spent surveying and collecting the region near Fox Creek

Divide. 48 TE655 refers to a series of closely spaced lithic scatters which radiate for approximately one-half mile to the south, southeast, and southwest of Fox Creek Pass. Artifacts are associated with areas of well developed soils and trees which provide excellent windscreens - an important factor for this relatively open stretch of high country at $9500^{\prime}$.

Encompassing a minimum of 3750 square meters and situated at the head of Fox Creek, the JEM site is the largest of these loci and may have served as a focal point for activity. Here 150 collecting units were laid out and artifact distributions plotted on graph paper. Preliminary analysis demonstrates a full compliment of tool types ranging from choppers to finelyflaked projectile points. Time depth is proven not only by the point types recovered (spanning the years from 4000 B.C. to ca. A.D. 1500) but also through the presence of subsurface components. Test Pit \#1 ( $|\times|$ meter) indicates the existence of at least two (2) levels. The upper level extends from the surface to approximately 23 centimeters below surface. A drop in lithic frequencies marks a transitional zone from ca. 23 centimeters to ca. 31 centimeters. Below 31 centimeters artifacts increase in frequency, indeed the absolute counts are greater than those in level I. The excavation unit reached only 45 centimeters below surface when work had to be discontinued. Further testing either to confirm or explain this lower level will be conducted during the 1979 field season.

\section{Discussion}

Two questions guide the present research: (1) are sites on the southern valley floor and those in the southern Tetons related, and (2) if they are, how can relationships be demonstrated? If loci are interrelated, then multivariate statistical analysis of site assemblages is an appropriate method for accepting or rejecting the validity of such an hypothesis. At this time, as mentioned above, data analysis is restricted to a sample of surface materials from Sawmill Ponds. The objective is to establish a reliable model for the discrimination and classification of tool types. Once perfected, this model can be applied to other assemblages in order to evaluate mathematically determined distances among site inventories. The academic year 1978-1979 should begin to provide some answers.

\section{Acknowledgments}

I wish to thank personnel of Grand Teton National Park for their continued assistance, in particular, Chief Naturalist Charles McCurdy. I am also indebted to the members of my field crew: Lee Kossin, Maureen Malloy, Liz Reeve, Mary Riford, and Jonathan Silverstein. This study was supported through a grant obtained through the National Park Service largely, if not totally due to the efforts and interests of F. A. Calabrese, Chief

Archaeologist, Midwest Archaeological Center, Lincoln.

\section{$\underline{\text { Literature Cited }}$}

Love, J. D. and J. C. Reed. 1975. Creation of the Teton landscape. Moose: Grand Teton Natural History Association. 